\title{
A SHORT-TERM FOLLOW-UP OF PATIENTS WITH MILD SCOLIOSIS
}

\author{
M. M. SCOTT, H. PIGGOTT \\ From the Royal Orthopaedic Hospital, Birmingham
}

\begin{abstract}
Thirty patients with mild idiopathic scoliosis were reviewed between 7 and 17 years after spinal maturity. These patients were not treated surgically because they were cosmetically acceptable, and unlikely to progress further. Standardised radiographs taken at spinal maturity and at review were comparable, so any change represented true progression in a fully mature spine. There was an increase of lateral curvature in 60 per cent of the patients; this was small and always under 10 degrees. No change was seen in rotation. Lateral curves over $\mathbf{3 0}$ degrees, with rotation of 25 degrees or more, were found to be almost twice as likely to progress. It is suggested that caution should be exercised in leaving these curves untreated, and follow-up into early adult life is advisable.
\end{abstract}

It has been the policy of the Birmingham Scoliosis Service not to advise surgical treatment for curves that are cosmetically acceptable at maturity, and which are of less than $\mathbf{4 5}$ degrees (or 50 degrees for double curves). Thirty patients, with accurately comparable radiographs and evidence that growth had ceased, were reviewed to see if this policy was justified. Change in the lateral curve and in rotation were measured. Many patients were excluded from this review either because the latest radiograph available did not show complete fusion of the iliac apophyses (progression of the curve may therefore have occurred before maturity) or because the maturity and review radiographs were not accurately comparable.

\section{CLINICAL MATERIAL AND METHODS}

The criteria applied in the selection of patients for this review were strict. Only those with mild scoliosis, where it was certain that growth had ceased and where the radiographs at review were accurately comparable to those at maturity, were included. These patients had not been operated on as their curves were cosmetically acceptable and thought unlikely to progress.

Fusion of the iliac apophyses was taken as an indication of spinal maturity (Risser 1948), and the patients were reviewed between 7 and 17 years later. Thirty patients who satisfied these criteria were re-examined by one of the authors (MMS).

An anteroposterior radiograph was taken at review; this was directly comparable to the radiograph taken at spinal maturity. Lateral curvature was measured by the Cobb technique. Rotation was measured at the apical vertebra by expressing the amount of displacement of the pedicle as a percentage of the entire width of the vertebral body (Nash and Moe 1969).

There were 24 women and six men. The average age at review was 28 years 1 month, and at skeletal maturity the average was 16 years 10 months for women and 17 years 5 months for men. The interval between measurements ranged from 7 years 5 months to 16 years 7 months (average 11 years). There were 16 thoracolumbar curves ( 53 per cent); eight thoracic ( 27 per cent); five double ( 17 per cent) and one lumbar. Sixty-three per cent were convex to the right and 37 per cent convex to the left.

\section{RESULTS}

The details of the 30 patients are shown in Table I. Lateral curvature. There were 35 curves in 30 patients. Twenty-one ( 60 per cent) showed an increase ranging from 2 to 10 degrees (average 5.6 degrees), 13 (37 per cent) were unchanged, and one decreased by three degrees. The ranges of increase for the different types of curves were similar, but slightly fewer of the thoracic curves increased compared to the thoracolumbar, or double curves. There was no correlation between the amount of progression and the number of vertebrae involved, nor did there seem to be any relationship to the direction of the curve or the interval between measurements.

When curves over 30 degrees were compared with those under 30 degrees, the range of increase was again similar, but 70 per cent of the greater curves increased compared with only 46 per cent of the lesser.

Rotation. Rotation ranged from 10 to 40 degrees (average 25 degrees), but no curve showed any measurable change in rotation between spinal maturity and review. More of the curves with rotation of 25 degrees or over increased (68 per cent), compared to those with rotation of under 25 degrees ( 46 per cent) although again, the range of increase was similar (Table II).

M. M. Scott, FRCSEd, Consultant Orthopaedic Surgeon, Blackburn Royal Infirmary, Bolton Road, Blackburn, Lancashire BB2 3LR, England. H. Piggott, FRCS, Consultant Orthopaedic Surgeon, Royal Orthopaedic Hospital, The Woodlands, Northfield, Birmingham B31 2 AP, England. Requests for reprints should be sent to Mr M. M. Scott.

(1) 1981 British Editorial Society of Bone and Joint Surgery 0301-620X/81/4107-0523\$2.00 
Table I. Details of the 30 patients

\begin{tabular}{|c|c|c|c|c|c|c|c|}
\hline $\begin{array}{c}\text { Patient } \\
\text { number }\end{array}$ & Sex & Curve & Direction & $\begin{array}{c}\text { Measurement } \\
\text { at maturity } \\
\text { (degrees) }\end{array}$ & $\begin{array}{c}\text { Increase or } \\
\text { decrease in } \\
\text { curve (degrees) }\end{array}$ & Rotation & $\begin{array}{l}\text { Interval between } \\
\text { measurement } \\
\text { (years) }\end{array}$ \\
\hline 1 & Female & $\begin{array}{l}\text { T6-T11 } \\
\text { T12-L4 }\end{array}$ & $\begin{array}{l}\text { Right } \\
\text { Left }\end{array}$ & $\begin{array}{l}26 \\
32\end{array}$ & $\begin{array}{l}8 \\
8\end{array}$ & $\begin{array}{l}15 \\
25\end{array}$ & 13 \\
\hline 2 & Female & $\begin{array}{l}\text { T6-T11 } \\
\text { T12-L4 }\end{array}$ & $\begin{array}{l}\text { Right } \\
\text { Left }\end{array}$ & $\begin{array}{l}53 \\
53\end{array}$ & $\begin{array}{l}5 \\
0\end{array}$ & $\begin{array}{l}35 \\
25\end{array}$ & 9 \\
\hline 3 & Female & $\begin{array}{l}\text { T6-T9 } \\
\text { T10-L2 }\end{array}$ & $\begin{array}{l}\text { Right } \\
\text { Left }\end{array}$ & $\begin{array}{l}25 \\
17\end{array}$ & $\begin{array}{l}0 \\
4\end{array}$ & $\begin{array}{l}15 \\
25\end{array}$ & 8.7 \\
\hline 4 & Female & $\begin{array}{l}\text { T5-T10 } \\
\text { T11-L3 }\end{array}$ & $\begin{array}{l}\text { Right } \\
\text { Left }\end{array}$ & $\begin{array}{l}48 \\
46\end{array}$ & $\begin{array}{l}0 \\
0\end{array}$ & $\begin{array}{l}30 \\
15\end{array}$ & 12.4 \\
\hline 5 & Female & $\begin{array}{l}\text { T5-T11 } \\
\text { T12-L4 }\end{array}$ & $\begin{array}{l}\text { Right } \\
\text { Left }\end{array}$ & $\begin{array}{l}36 \\
38\end{array}$ & $\begin{array}{l}5 \\
6\end{array}$ & $\begin{array}{l}25 \\
20\end{array}$ & 8 \\
\hline 6 & Female & $\mathrm{T} 5-\mathrm{T} 12$ & Right & 43 & 2 & 25 & 8.7 \\
\hline 7 & Female & T5-T10 & Right & 42 & 9 & 25 & 7.9 \\
\hline 8 & Male & T5-T11 & Right & 42 & 0 & 30 & 8.5 \\
\hline 9 & Male & $\mathrm{T} 5-\mathrm{T} 12$ & Right & 42 & 0 & 30 & 11.2 \\
\hline 10 & Female & T9-L2 & Left & 42 & 2 & 25 & 7.9 \\
\hline 11 & Female & T9-L3 & Right & 40 & 5 & 35 & 16.7 \\
\hline 12 & Female & T8-L1 & Right & 40 & 4 & 30 & 13.2 \\
\hline 13 & Female & T5-L1 & Right & 38 & 7 & 35 & 13.5 \\
\hline 14 & Female & T10-L4 & Left & 36 & 3 & 25 & 13.7 \\
\hline 15 & Female & T3-T11 & Left & 35 & 7 & 20 & 8.5 \\
\hline 16 & Female & T9-L1 & Right & 34 & 8 & 25 & 8.2 \\
\hline 17 & Female & T8-L2 & Right & 30 & 7 & 40 & 12 \\
\hline 18 & Male & T5-T12 & Right & 30 & 0 & 20 & 13.2 \\
\hline 19 & Female & $\mathrm{T} 8-\mathrm{L} 1$ & Right & 26 & 3 & 25 & 13.8 \\
\hline 20 & Male & T11-L4 & Left & 20 & 4 & 20 & 14.4 \\
\hline 21 & Female & T9-L4 & Left & 19 & 0 & 25 & 12.8 \\
\hline 22 & Female & T6-T12 & Right & 17 & 10 & 25 & 7.5 \\
\hline 23 & Female & T12-L4 & Right & 16 & 0 & 30 & 14.1 \\
\hline 24 & Female & T4-T10 & Right & 12 & 0 & 15 & 11.5 \\
\hline 25 & Female & T12-L4 & Left & 12 & -3 & 10 & 10 \\
\hline 26 & Female & T7-L2 & Right & 12 & 0 & 25 & 11.5 \\
\hline 27 & Male & L1-L4 & Left & 10 & 0 & 20 & 9.5 \\
\hline 28 & Female & T5-L1 & Right & 7 & 2 & 20 & 10.5 \\
\hline 29 & Male & T9-L1 & Right & 6 & 0 & 15 & 9.7 \\
\hline 30 & Female & T11-L5 & Left & 5 & 8 & 20 & 15 \\
\hline
\end{tabular}


Table II. The percentage of curves which increased and the range of increase according to the type of curve

\begin{tabular}{|l|c|c|}
\hline \multicolumn{1}{|c|}{ Type of curve } & $\begin{array}{c}\text { Percentage of curves } \\
\text { which increased }\end{array}$ & $\begin{array}{c}\text { Range of increase } \\
\text { (degrees) }\end{array}$ \\
\hline All & 60 & -3 to 10 \\
Thoracolumbar & 68 & -3 to 8 \\
Thoracic & 50 & 2 to 10 \\
Double & 60 & 4 to 8 \\
Curves $<30$ degrees & 46 & -3 to 10 \\
Curves $>30$ degrees & 70 & 2 to 9 \\
Rotation $<25$ degrees & 46 & -3 to 8 \\
Rotation $>25$ degrees & 68 & 2 to 10 \\
\hline
\end{tabular}

\section{DISCUSSION}

Risser and Ferguson (1936) believed that progression of scoliosis ceased when the spine was mature. More recently it has been realised that there is a slower, but sometimes significant progression after spinal maturity. Degeneration of the intervertebral disc has been held responsible (Risser 1964; Harrington 1977; Risser, Iqbal and Nagata 1977), but Collis and Ponsetti (1969) who reported an average increase of 15 degrees in scoliosis curves after spinal maturity, could only identify one case as being due to degeneration of the intervertebral disc.
These reports have been concerned largely with severe, untreated curves reviewed in late adult life. A search of the literature revealed no information about the progression of untreated, mild curves in the first two decades after spinal maturity, and the purpose of this review is an early assessment to check that by leaving mild curves untreated at maturity we are not condemning patients to cosmetically unacceptable spines in early and middle adult life.

Since the radiographs taken at maturity and at review were strictly comparable, any difference found represented true progression in a fully mature spine; an increase in the lateral curve was seen in 60 per cent of the patients, but it was small and never more than 10 degrees. No evidence of degeneration of the disc was seen in our series, but this may be a feature appearing in middle and old age. No increase in rotation was seen but small changes may easily escape detection. Although we failed to identify any particular type of curve that was more liable to progress, we found that the largest percentage increase occurred in lateral curves over 30 degrees and in curves with rotation of 25 degrees or over.

These types of curve should be carefully considered before allowing them to go untreated as further progression is likely to occur in middle and old age. A triennial review proceeding to a quinquennial review after spinal maturity may be advisable before they are discharged from follow-up.

\section{REFERENCES}

Collis DK, Ponsetti IV. Long-term follow-up of patients with idiopathic scoliosis not treated surgically. J Bone Joint Surg [Am] 1969;51-A:425-45.

Harrington PR. The etiology of idiopathic scoliosis. Clin Orthop 1977;126:17-25.

Nash CL Jr, Moe JH. A study of vertebral rotation. J Bone Joint Surg [Am] 1969;51-A:223-9.

Risser JC. Important practical facts in the treatment of scoliosis. Instruct Lect Amer Acad Orthop Surg 1948;5:248-60.

Risser JC. Scoliosis past and present. J Bone Joint Surg [Am] 1964;46-A:167-99.

Risser JC, Ferguson AB. Scoliosis: its prognosis. J Bone Joint Surg 1936;18:667-70.

Risser JC, Iqbal QM, Nagata K. Scoliosis after termination of vertebral growth. Ann R Coll Surg Engl 1977;59:119-23. 